\title{
Efektivitas Peran ASEAN dalam Mengatasi Masalah Human Security di Kawasan Asia Tenggara ${ }^{1}$
}

\author{
Achmad Zulfikar \\ Jurusan Ilmu Hubungan Internasional \\ Universitas Muhammadiyah Yogyakarta \\ Email: apa@kabarfikar.com
}

\begin{abstract}
Currently there are no indicators that can measure the effectiveness of the role of ASEAN in Southeast Asia, especially those related to human security issues. Though this indicator can be used as an evaluation tool for an institution to assess the success rate, as well as things that are considered necessary to be addressed. This paper will further analyze the human security issues in Southeast Asia starting with conceptualizing, identifying, and engaging. Based on the above three stages of analysis it will show the problems that have been handled and have not been done by ASEAN institutionally. In addition to showing the relevance of the establishment of ASEAN Political-Security Community (APSC) 2015 as an affirmation for all ASEAN member countries to respond to institutional human security issues, this paper will also answer the research question: How is the effectiveness of ASEAN's role in addressing Human Security issues in Southeast Asia Region?
\end{abstract}

Keywords: Efectivity, ASEAN, Human Security

\begin{abstract}
Abstrak
Saat ini belum ada indikator yang dapat mengukur efektivitas peran ASEAN di kawasan Asia Tenggara khususnya yang terkait masalah keamanan manusia. Padahal indikator ini dapat dijadikan alat evaluasi bagi suatu institusi untuk menilai tingkat keberhasilan, maupun hal-hal yang dianggap perlu dibenahi. Lebih lanjut tulisan ini akan melakukan analisis terhadap permasalahan keamanan manusia di kawasan Asia Tenggara dimulai dengan melakukan konseptualisasi, identifikasi, dan keterlibatan. Berdasarkan tiga tahapan analisis di atas kemudian akan menunjukkan permasalahan yang telah ditangani maupun belum dilakukan oleh ASEAN secara institusional. Selain memperlihatkan relevansi dibentuknya ASEAN Political-Security Community (APSC) 2015 sebagai penegasan bagi seluruh negara anggota ASEAN untuk merespon permasalahan keamanan manusia secara institusional, tulisan ini juga akan menjawab pertanyaan riset: Bagaimana efektivitas peran ASEAN dalam mengatasi masalah Human Security di Kawasan Asia Tenggara?
\end{abstract}

Kata Kunci: Efektivitas, ASEAN, Human Security

\footnotetext{
1 Makalah telah dikompetisikan pada Lomba Karya Tulis Ilmiah se-Indonesia "How ASEAN as an Institutional Platform Can Address the Security Problem in the Region? yang diselenggarakan oleh Program Studi Hubungan Internasional, Fakultas Ilmu Sosial dan Politik dan Kelompok Studi Mahasiswa Pengkaji Masalah Internasional (KSMPMI), Universitas Katolik Parahyangan. Dipresentasikan di hadapan dewan juri pada 6 Mei 2013.
} 


\section{Latar Belakang}

The Association of Southeast Asian Nations (ASEAN) merupakan organisasi regional di kawasan Asia Tenggara yang terdiri dari 10 negara yang didirikan 8 Agustus 1967 oleh Indonesia, Malaysia, Filipina, Singapura, dan Thailand. Sejak pendiriannya anggota ASEAN telah meliputi Brunei Darussalam, Myanmar, Kamboja, Laos, dan Vietnam.

Dalam dokumen pendirian ASEAN (The ASEAN Declaration/The Bangkok Declaration) menyebutkan bahwa maksud dan tujuan pertama didirikannya ASEAN adalah untuk mempercepat pembangunan ekonomi, kemajuan sosial, dan perkembangan kejayaan di kawasan guna memperkuat dasar bagi sebuah komunitas yang sejahtera dan damai di Asia Tenggara. Adapun maksud dan tujuan kedua untuk meningkatkan perdamaian dan stabilitas kawasan (ASEAN, n.d.) .

Secara geopolitik kondisi negara-negara di kawasan Asia Tenggara sangat rentan untuk terjadi konflik dikarenakan posisinya yang sangat berdekatan satu sama lain. Di samping itu, kecenderungan timbulnya konflik bila teral dan multilateral terkadang tidak dapat dihindarkan. Namun seiring berjalannya waktu, konflik maupun ancaman tradisional seperti perang antar-negara mulai ditinggalkan dan berganti ke konsep keamanan yang mengarah pada kepentingan kemanusiaan.

Peralihan ini mulai terlihat pasca perang dingin, dan terjadi dengan sangat cepat. Berbagai fokus wacana keamanan yang dahulu terkait dengan isu militer dan politik bergeser ke isu yang lebih berkaitan dengan kondisi hidup individu dan masyarakat.

Setelah runtuhnya perang dingin, konsep keamanan dalam sistem mengalami pergeseran secara cepat. Pergeseran itu meliputi perubahan fokus wacana keamanan dari isu militer dan politik ke isu yang terkait dengan kondisi hidup individu dan masyarakat, dari fokus negara ke masyarakat dan pergeseran dari konsep keamanan nasional menjadi keamanan manusia.

Hal ini dipicu perkembangan negara-negara ASEAN yang kini tidak dibayangi lagi oleh musuh eksternal, tetapi lebih banyak direcoki oleh masalah-masalah internal seperti gerakan separatis dan gerakan demokratisasi. Dalam menghadapi persoalan internal ini banyak rezim politik lebih memprioritaskan kelangsungan hidup rezim dengan mengedepankan aksi kekerasan dan mengabaikan keselamatan dan kondisi hidup masyarakat, sehingga prinsip keamanan manusia ini harus kita evaluasi lebih lanjut.

Dalam memahami beberapa kasus terkait dengan keamanan manusia maupun individu, dapat kita lihat contoh dari peristiwa krisis ekonomi tahun 1997, di sini kita dapat melihat dampak dari merosotnya kondisi ekonomi yang mengakibatkan kehancuran daya hidup orang-per orang dan masyarakat, terutama dari kalangan bawah. Pada peristiwa tersebut, perekonomian dan angka pengangguran meningkat di hampir setiap negara, sementara itu hampir tidak ada mekanisme nasional dan regional yang mampu menyediakan jaring pengaman sosial dengan cepat dan efektif. Lebih lanjut lagi, peristiwa Tsunami pada Desember 2004 juga semakin memperkuat argumentasi bahwa subyek paling penting yang harus diamankan adalah manusia secara individual, bukan lagi negara.

Dalam beberapa dekade terakhir ancaman terhadap keamanan manusia di kawasan Asia Tenggara semakin meningkat ekskalasinya dalam berbagai isu seperti: bencana alam (misalnya Tsunami, gempa bumi Yogyakarta, banjir dan letusan gunung api di Filipina dan 
Indonesia, isu kesehatan (HIV/AIDS, dan flu burung), isu lingkungan (asap dan penggundulan hutan), jaring pengaman sosial dalam situasi krisis, perdagangan manusia transnasional, hingga kasus Hak Asasi Manusia (misalnya kasus Myanmar).

Serangkaian isu di atas menunjukkan bahwa individu semakin menjadi referensi utama dalam soal keamanan. Serangkaian isu diatas membutuhkan kemauan kolektif negaranegara anggota ASEAN untuk mengembangkan kapabilitas dalam rangka mengatasi persoalan-persoalan tersebut secara efektif. Dalam tulisan ini, penulis akan mengadakan pengukuran terhadap efektivitas peran ASEAN dalam mengatasi masalah Keamanan Manusia di Kawasan Asia Tenggara berdasarkan aspek konseptualisasi, identifikasi, tingkat keterlibatan, dan rekomendasi solusi.

Dengan demikian, tulisan ini akan menjawab pertanyaan penelitian: Bagaimana efektivitas peran ASEAN dalam mengatasi masalah Human Security di Kawasan Asia Tenggara?

\section{Mendefinisikan Konsep Human Security}

Menurut Mantan Sekretaris Jendral Perserikatan Bangsa-Bangsa (PBB) Kofi Annan (2000a) terkait dengan konsep keamanan manusia, ia menyatakan bahwa konsep keamanan kini telah berevolusi. Adapun kebutuhan utama saat ini adalah pendekatan terhadap kemanusiaan yangmana keaman an manusia ini terancam oleh senjata pemusnah massal, maupun aspek lainnya yang terkait dengan kemanusiaan tersebut.

"In the wake of these conflicts, a new understanding of the concept of security is evolving. Once synonymous with the defence of territory from external attack, the requirements of security today have come to embrace the protection of communities and individuals from internal violence. The need for a more human-centred approach to security is reinforced by the continuing dangers that weapons of mass destruction, most notably nuclear weapons, pose to humanity: their very name reveals their scope and their intended objective, if they were ever used."

Lebih lanjut Kofi Annan (2000) memaparkan bahwa keamanan manusia mencakup hal yang luas seperti HAM, hak untuk mendapatkan pendidikan dan kesehatan, serta kebebasan dalam berbagai aspek.

"Human security, in its broadest sense, embraces far more than the absence of violent conflict. It encompasses human rights, good governance, access to education and health care and ensuring that each individual has opportunities and choices to fulfill his or her potential. Every step in this direction is also a steep towards reducing poverty, achieving economic growth and preventing conflict. Freedom from want, freedom from fear, and the freedom of future generations to inherit a healthy natural environment - these are the interrelated building blocks of human - and therefore national - security.”

Mantan Komisioner PBB untuk Pengungsi Sadako Ogata (1998) menekankan empat elemen penting yang mempengaruhi keamanan manusia yang harus diperhatikan oleh siapapun dan dimanapun. Elemen-elemen tersebut antara lain ruang untuk hidup aman dan damai, perlakuan tanpa diskriminasi, persamaan hak dalam berpolitik dan hukum. 
"Several key elements make up human security. The first essential element is the possibility for all citizens to live in peace and security within their own borders. This implies the capacity of states and citizens to prevent and resolve conflicts through peaceful and nonviolent means and, after the conflict is over, the ability to effectively carry out reconciliation efforts. A second element is that people should enjoy without discrimination all rights and obligations - including human, political, social, economic and cultural rights - that belonging to a State implies. A third element is social inclusion - or having equal access to the political, social and economic policy making processes, as well as to draw equal benefits from them. A fourth element is that of the establishment of rule of law and the independence of the justice system. Each individual in a society should have the same rights and obligations and be subject to the same set of rules. These basic elements which are predicated on the equality of all before the law, effectively remove any risk of arbitrariness which so often manifests itself in discrimination, abuse or oppression."

Sadako Ogata (1999) juga mengingatkan ancaman terhadap keamanan manusia yang juga menitikberatkan pada aspek sosial, ekonomi, dan lingkungan, serta hal-hal yang membuat masyarakat merasa tidak nyaman.

"Threats to human security are varied - political and military, but also social, economic and environmental. A wide array of factors contribute to making people feel insecure, from the laying of landmines and the proliferation of small arms, to transnational threats such as drugs trafficking, to the spread of HIV. Once again, therefore, let me speak of human insecurity from my perspective. Refugees flee conflicts. One of the main factors of human insecurity is precisely the lack of effective political and security mechanisms to address conflicts."

Human Security Network (n.d.) mendefinisikan beberapa poin terkait dengan keamanan manusia yang berhubungan langsung dengan hak asasi tiap individu.

"A humane world where people can live in security and dignity, free from poverty and despair, is still a dream for many and should be enjoyed by all. In such a world, every individual would be guaranteed freedom from fear and freedom from want, with an equal opportunity to fully develop their human potential. Building human security is essential to achieving this goal. In essence, human security means freedom from pervasive threats to people's rights, their safety or even their lives."

Sedangkan konsep utama yang digagas oleh United Nations Development Programme (UNDP, 1994) mendefinisikan konsep keamanan manusia yakni keamanan yang mencakup keselamatan dari ancaman kronis seperti ekonomi, kelaparan, penyakit, lingkungan dan tindakan represis sehingga setiap individu harus mendapat perlindungan dari berbagai gangguan yang membahayakan kehidupan mereka sehari-hari dan berdampak terhadap keberadaan masyarakat secara luas.

"Human security can be said to have two main aspects. It means, first, safety from such chronic threats as hunger, disease and repression. And second, it means protection from sudden and hurtful disruptions in the patterns of daily life - whether 
in homes, in jobs or in communities. Such threats can exist at all levels of national income and development."

Dari definisi di atas, UNDP (1994) merumuskan tujuh area yang menjadi aspek utama dalam masalah keamanan kemanusiaan ini. Konsep ini pertama kali dikemukakan oleh Dr. Mahbub ul Haq yang menggugah perhatian dunia terhadap keamanan yang sangat vital ini. Tujuh area tersebut antara lain: keamanan ekonomi, ketahanan pangan, jaminan kesehatan, keamanan lingkungan, keamanan pribadi, keamanan komunitas, dan keamanan politik.

1) Keamanan ekonomi - memberikan jaminan terhadap penghasilan dasar bagi individu, biasanya dari pekerja produktif atau, sebagai pilihan terakhir, dari pembiyaan terhadap jaring pengaman publik. Dalam pengertian ini, hanya sekitar seperempat dari penduduk dunia yang saat secara ekonomi aman. Sementara masalah keamanan ekonomi mungkin lebih serius di negara-negara berkembang, kekhawatiran juga timbul di negara-negara maju juga. Masalah pengangguran merupakan faktor penting yang mendasari ketegangan politik dan kekerasan etnis.

2) Ketahanan pangan - mensyaratkan bahwa semua orang setiap saat memiliki akses fisik dan ekonomi terhadap pangan pokok. Menurut PBB, ketersediaan keseluruhan makanan tidak menjadi masalah, namun yang menjadi pokok permasalahan adalah distribusi miskin makanan dan kurangnya daya beli. Di masa lalu, masalah ketahanan pangan telah ditangani dengan baik di tingkat nasional maupun global. Namun, dampaknya terbatas. Menurut PBB, kuncinya adalah untuk mengatasi masalah yang berkaitan dengan akses ke aset, pekerjaan dan pendapatan terjamin (yang berkaitan dengan keamanan ekonomi).

3) Jaminan kesehatan - bertujuan untuk menjamin perlindungan minimal dari penyakit dan gaya hidup tidak sehat. Di negara berkembang, penyebab utama kematian tradisional adalah penyakit infeksi dan parasit, sedangkan di negaranegara industri, para pembunuh utama adalah penyakit pada sistem peredaran darah. Saat ini, gaya hidup yang berhubungan dengan penyakit kronis memimpin pembunuh di seluruh dunia, dengan 80 persen kematian akibat penyakit kronis yang terjadi di negara-negara berpenghasilan rendah dan menengah. Menurut $\mathrm{PBB}$, ancaman terhadap kesehatan di negara-negara berkembang dan industri biasanya lebih besar mempengaruhi orang-orang miskin di daerah pedesaan, terutama anak-anak. Hal ini karena akses malnutrisi dan pelayanan kesehatan yang cukup, air bersih dan kebutuhan dasar lainnya.

4) Keamanan lingkungan - bertujuan untuk melindungi masyarakat dari kerusakan akibat jangka pendek dan jangka panjang dari alam, buatan manusia, ancaman dari alam, maupun kerusakan lingkungan alam. Di negara berkembang, kurangnya akses untuk membersihkan sumber daya air merupakan salah satu ancaman lingkungan terbesar. Di negara-negara industri, salah satu ancaman utama adalah polusi udara. Pemanasan global, yang disebabkan oleh emisi gas rumah kaca, merupakan masalah keamanan lingkungan.

5) Keamanan pribadi - bertujuan untuk melindungi masyarakat dari kekerasan fisik, baik dari (internal) negara atau eksternal. Beberapa hal terkait dengan keamanan pribadi antara kekerasan dalam rumah tangga, atau dari orang dewasa. Bagi 
banyak orang, sumber terbesar dari kecemasan adalah kejahatan, khususnya kejahatan kekerasan.

6) Keamanan komunitas - bertujuan untuk melindungi orang dari hilangnya hubungan tradisional dan nilai-nilai dan dari kekerasan sektarian dan etnis. Masyarakat tradisional, khususnya kelompok minoritas etnis sering terancam. Sekitar setengah dari negara -negara di dunia telah mengalami beberapa konflik antar-etnis. PBB bahkan menyoroti kerentanan terus-menerus dari 300 juta penduduk asli di 70 negara yang menghadapi pelebaran lingkaran kekerasan.

7) Keamanan politik - berkaitan dengan apakah orang hidup dalam masyarakat yang menghormati hak-hak dasar mereka sebagai manusia. Menurut sebuah survei yang dilakukan oleh Amnesti Internasional, represi politik, penyiksaan sistematis, dan perlakuan buruk masih dipraktekkan di 110 negara. Pelanggaran hak asasi manusia yang paling sering selama periode kerusuhan politik. Seiring dengan individu dan kelompok menindas, pemerintah mungkin mencoba untuk melakukan kontrol atas ide-ide dan informasi.

Sejak digulirkannya tujuh area fokus dalam mengkaji keamanan manusia oleh UNDP. Seiring berjalannya waktu, maka isu ini mulai mendapatkan perhatian dari masayarakat Internasional yang menginginkan terjadinya perbaikan ke arah yang lebih baik mengenai penanganan keamanan manusia (Bajpai, 1999).

Seorang akademisi dan analis dari India Kanti Bajpai (2000) menyatakan bahwa keamanan manusia sangat terkait dengan perlindungan dar i keselamatan pribadi dan kebebasan dari ancaman langsung maupun tidak langsung.

"Human security relates to the protection of the individual's personal safety and freedom from direct and indirect threats of violence. The promotion of human development and good governance, and, when necessary, the collective use of sanctions and force are central to managing human security. States, international organizations, nongovernmental organizations, and other groups in civil society in combination are vital to the prospects of human security."

Berdasarkan definisi dari institusi internasional, hingga akademisi di atas maka definisi mengenai konsep Keamanan Manusia. Pada intinya fokus utama dari konsep keamanan manusia ini adalah pengutamaan individu sebagai subyek yang harus diamankan. Konsep keamanan manusia memiliki arera yang luas, namun UNDP 1994 memfokuskan pada 7 area yakni keamanan ekonomi, ketahanan pangan, jaminan kesehatan, keamanan lingkungan, keamanan pribadi, keamanan komunitas, dan keamanan politik.

Setelah menelaah beberapa konsep terkait keamanan manusia, apabila kita menilik pada konsep keamanan manusia di ASEAN, walupun telah termanifestasi di dalam rencana dan program, namun hingga kini masih belum ada konsensus yang jelas menyangkut apa makna keamanan manusia dan bagaimana isu keamanan manusia seharusnya ditangani di Asia Tenggara.

Hal ini terjadi karena masih adanya ambiguitas dalam memaknai konsep keamanan manusia dan masih beragamnya prioritas kebijakan masing - masing negara anggota ASEAN menyangkut keamanan manusia. Sampai saat ini hanya Filipina saja yang telah memiliki regulasi mengenai keamanan manusia yakni Human Security Act 2007, begitupun Thailand 
yang sejak 2003 memiliki Kementerian Pembangunan Sosial dan Keamanan Manusia. Padahal untuk menjawab isu keamanan manusia membutuhkan kerjasama dan tindakan bersama dalam berbagai cakupan: lokal, regional dan global, yang terkadang mengabaikan batas-batas teritorial negara.

\section{Human Security di ASEAN: Dulu, Sekarang, dan Akan Datang}

Pada bagian ini penulis berusaha untuk melakukan identifikasi terhadap isu-isu keamanan manusia di Asia Tenggara yang telah dan sedang terjadi. Selanjutnya dari hasil identifikasi ini akan diprediksikan hal-hal apa saja yang menjadi prioritas bagi ASEAN sebagai organisasi regional untuk diselesaikan.

Isu yang akan diangkat akan berbicara seputar 7 area dari keamanan manusia seperti yang telah dibahas sebelumnya yakni (1) keamanan ekonomi, (2) ketahanan pangan, (3) jaminan kesehatan, (4) keamanan lingkungan, (5) keamanan pribadi, (6) keamanan komunitas, dan (7) keamanan politik.

\begin{tabular}{|c|c|c|c|c|}
\hline No. & Peristiwa & Kategori & Area & $\begin{array}{l}\text { Keterlibatan } \\
\text { ASEAN }\end{array}$ \\
\hline 1. & $\begin{array}{l}\text { Tenaga Kerja Ilegal dari } \\
\text { Indonesia, Filipina, dan } \\
\text { Myanmar ke Malaysia dan } \\
\text { Singapura }\end{array}$ & $\begin{array}{l}\text { Perdagangan } \\
\text { Manusia }\end{array}$ & $(5)$ & Belum \\
\hline 2. & $\begin{array}{l}\text { Aksi Bom Bali I (2002) di } \\
\text { Bali, Indonesia }\end{array}$ & Terorisme & $\begin{array}{l}(5)(6) \\
(7)\end{array}$ & $\begin{array}{l}\text { Ada (ASEAN } \\
\text { Ministerial Meeting on } \\
\text { Transnational Crime } \\
\text { (AMMTC), Rencana } \\
\text { aksi melawan } \\
\text { Terorisme) }\end{array}$ \\
\hline 3. & $\begin{array}{l}\text { Pengungsi Myanmar ke } \\
\text { Indonesia, Thailand, dan } \\
\text { Malaysia }\end{array}$ & $\begin{array}{l}\text { Perdagangan } \\
\text { Manusia }\end{array}$ & $\begin{array}{l}\text { (1) }(2) \\
\text { (3) }(6)\end{array}$ & Belum \\
\hline 4. & $\begin{array}{l}\text { Proses Demokratisasi } \\
\text { Myanmar yang berimplikasi } \\
\text { terjadinya pelanggaran HAM }\end{array}$ & Demokrasi & $\begin{array}{l}(5)(6) \\
(7)\end{array}$ & Belum \\
\hline 5. & Tsunami di Aceh (2004) & Bencana Alam & $\begin{array}{l}(4)(5) \\
(6)\end{array}$ & Belum \\
\hline 6. & $\begin{array}{l}\text { Topan Nargis di Myanmar } \\
(2008)\end{array}$ & Bencana Alam & (4) $(5)$ & $\begin{array}{l}\text { Ada (TCG: PBB- } \\
\text { ASEAN-Myanmar) }\end{array}$ \\
\hline 7. & $\begin{array}{l}\text { Perdagangan Obat-Obatan dari } \\
\text { Pabrik Narkoba di Segitiga } \\
\text { Emas (Thailand-Laos- } \\
\text { Myanmar) }\end{array}$ & $\begin{array}{l}\text { Perdagangan } \\
\text { Obat-Obatan }\end{array}$ & (3) $(5)$ & $\begin{array}{l}\text { Ada (Bangkok } \\
\text { Political Declaration } \\
\text { in Pursuit of Drug- } \\
\text { Free ASEAN 2015) }\end{array}$ \\
\hline 8. & $\begin{array}{l}\text { Pembajakan Kapal di Selat } \\
\text { Malaka }\end{array}$ & Pembajakan & (1) (5) & Belum \\
\hline 9. & $\begin{array}{l}\text { Kebakaran dan Penebangan } \\
\text { Hutan di Kalimantan dan } \\
\text { Sumatera, Indonesia }\end{array}$ & Lingkungan & $\begin{array}{l}\text { (1) }(3) \\
\text { (4) }(5)\end{array}$ & $\begin{array}{l}\text { Ada (The ASEAN } \\
\text { Agreement on } \\
\text { Transboundary Haze } \\
\text { Pollution) }\end{array}$ \\
\hline
\end{tabular}




\begin{tabular}{|l|l|l|l|l|}
\hline 10. & $\begin{array}{l}\text { Krisis Pangan di Indonesia } \\
(1999)\end{array}$ & Ketahanan Pangan & $\begin{array}{l}(1)(2) \\
(5)\end{array}$ & Belum \\
\hline
\end{tabular}

Berdasarkan tabel di atas, terdapat beberapa hal yang dapat disimpulkan sebagai berikut:

Pertama, keamanan pribadi merupakan poin paling penting yang menyentuh seluruh peristiwa yang pernah terjadi di ASEAN, karena hal tersebut menyangkut dengan kondisi dari masyarakat, apakah mereka merasa terancam atau tidak. Tentunya hampir seluruh peristiwa yang terjadi memberikan ancaman terhadap masyarakat baik secara sadar maupun tidak. Sehingga rekomendasi untuk penanganan berbagai konflik atau permasalahan di ASEAN sebaiknya mempertimbangkan aspek keamanan pribadi sebagai salah satu prioritas.

Kedua, terkait dengan keterlibatan ASEAN dalam penanganan atau penyelesaian kasus. Dari 10 kasus yang dipaparkan di atas hanya 4 kasus yang mendapatkan respon dari ASEAN. Dalam hal ini kita harus melihat ASEAN sebagai institusi dan bukan hanya diwakili oleh keberadaan negara yang sedang menjabat sebagai Ketua pada periode tersebut. Sehingga indikator keterlibatan ASEAN dalam mendorong terciptanya keamanan manusia masih kurang berdasarkan tabel di atas.

Ketiga, ASEAN harus mengintensifkan aksi bersama (collective action) dalam merespon isu-isu keamanan manusia, jika seluruh negara ASEAN memakai perspektif yang sama dalam memandang bahwa perlindungan kepada masyarakat merupakan prioritas bersama, maka hambatan-hambatan yang selama ini ada dapat dikesampingkan untuk suatu aksi kemanusiaan.

Dalam rangka menatap masa depan ASEAN yang lebih baik, maka dianggap perlu untuk mengenali ancaman-ancaman keamanan manusia di kawasan Asia Tenggara yang masih berlangsung, berulang-ulang, dan belum ada penyelesaian. Sehingga dapat dicarikan penanganan dan pencegahannya. Berikut dipaparkan beberapa diantaranya.

Pelanggaran Hak Asasi Manusia. Permasalahan ini masih menjadi ancaman bagi warga negara di hampir seluruh negara anggota ASEAN, sebut saja Indonesia pada era kepemimpinan Soeharto yang memiliki catatan panjang dalam kasus pelanggaran HAM berat (Kontras, n.d.). Begitupula Junta Militer di Myanmar yang yang hingga kini masih melakukan diskriminasi dan kekerasan terhadap etnis yang tidak diakuinya sebagai warga negara (Nugraha, 2013). Malaysia juga masih tetap mengekang rakyat dan pers dalam hal kebebasan berekspresi (Human Right Watch, 2013). Serta Perdana Menteri Kamboja Hun Sen yang melakukan pengekangan terhadap pesaing politiknya untuk melanggengkan kekuasaan yang telah dijabatnya selama 27 tahun (Human Right Watch, 2013).

Permasalahan Buruh Migran. Permasalahan ini seringkali menjadi pemicu eskalasi konflik bilateral antar-negara anggota ASEAN. Mari kita perhatikan antara IndonesiaMalaysia, hubungan di antara keduanya seringkali memanas ketika buruh migran Indonesia yang bekerja di Malaysia menerima perlakuan kasar dari majikannya dan terekspos oleh media (Suara Pembaruan, 2012). Tidak hanya itu, Indonesia-Singapura kerap mengalami permasalahan terkait pengupahan buruh migran yang tidak adil oleh agensi di Singapura (The Jakarta Post, 2013).

Permasalahan Lingkungan. Terkait hal ini yang seringkali menjadi permasalahan utama di ASEAN adalah pembalakan hutan (deforestation) dan kabut asap (haze). Dalam hal 
kepemilikan hutan, Indonesia masih menjadi tumpuan negara anggota ASEAN dan dunia, namun kegiatan pembalakan liar masih sering terjadi. Sehingga diperlukan upaya preventif dan penanganan yang efektif untuk tetap menjadikan Indonesia sebagai paru-paru dunia (Wharton School of the University of Pennsylvania, 2012). Sedangkan kabut asap (haze) yang menjadi masalah 'besar' bagi negara anggota ASEAN, kebakaran yang menimbulkan kabut asap di periode 1997-1998 tercatat sebagai peristiwa yang paling berdampak bagi Brunei Darussalam, Indonesia, Malaysia, Filipina, Singapura dan Thailand, dan yang terbaru pada periode 2007-2008 Kamboja, Laos, Myanmar dan Thailand kembali terkena dampaknya, maka tidak salah ketika ASEAN menanggapinya dengan serius melalui The ASEAN Agreement on Transboundary Haze Pollution, karena sewaktu-waktu peristiwa ini dapat terjadi kembali (ASEAN Secretariat, n.d.).

Kejahatan Transnasional. Perdagangan manusia, narkoba, dan terorisme merupakan masalah global yang tergolong dalam kejahatan transnasional, serta melibatkan negara anggota ASEAN di dalamnya. Seperti perdagangan manusia, banyak diantara korbannya berasal dari negara berkembang di kawasan Asia Tenggara. Sejalan dengan hal tersebut, rilis dari Department of State United States of America (2010), menyatakan bahwa kawasan Asia Tenggara digolongkan sebagai kawasan yang belum maksimal dalam penanganan perdagangan Buktinya sampai tahun 2010, hanya lima negara yang meratifikasi undangundang mengenai perdagangan manusia, yaitu Filipina, Brunei Darussalam, Myanmar, Kamboja dan Indonesia. Upaya untuk memberantas Narkoba telah ditunjukkan oleh ASEAN melalui kesepakatan yang tertuang dalam Bangkok Political Declaration in Pursuit of DrugFree ASEAN 2015, namun berdasarkan laporan United Nations Office on Drugs and Crime (UNODC) Regional Centre for East Asia and the Pacific tentang status dan rekomendasi terhadap Drug-Free ASEAN 2015 upaya yang dilakukan oleh negara-negara anggota ASEAN masih belum maksimal (UNODC, 2008). Sedangkan permasalahan yang terkait dengan terorisme masih terus mengancam stabilitas keamanan negara-negara anggota ASEAN, walaupun rencana aksi diadakan secara rutin dalam ASEAN Ministerial Meeting on Transnational Crime (AMMTC), namun upaya masing-masing negara untuk menindak gerakan terorisme sebelum melakukan ekspansi ke negara anggota lainnya sangat dibutuhkan (ASEAN, 2011).

\section{Inisiatif-Inisiatif dalam Menangani Permasalahan Keamanan Manusia di Kawasan Asia Tenggara}

Inisiatif ASEAN sebagai Institusi: Tinjauan terhadap Kontribusi ASEAN Political-Security Community (APSC) 2015

Peta jalan menuju integrasi Komunitas ASEAN 2015 sudah semakin dekat, berbagai persiapan tentunya telah dan sedang dilakukan oleh seluruh negara anggota ASEAN. Salah satu integrasi yang menarik untuk ditinjau adalah ASEAN Political-Security Community (APSC) yang berorientasi terhadap penanganan masalah politik dan keamanan sebagai bagian dari komunitas ASEAN.

Dalam blueprint ASEAN Political-Security Community (2015) terdapat berbagai macam hal yang dibahas terkait aspek politik dan keamanan. Namun ada bagian yang paling 
penting untuk dilihat bersama terkait dengan penanganan keamanan manusia, walaupun dinyatakan sebagai isu keamanan non -tradisional.

Tujuan utama ASEAN ialah merespon secara efektif dan tepat guna, berdasarkan prinsip keamanan yang komprehensif terhadap segala bentuk ancaman, tindakan kriminal antar-negara dan tantangan antar-wilayah.

Beberapa fokus dari isu non-tradisional ini antara lain perdagangan manusia, terorisme, perdagangan narkoba, pencurian ikan, perdagangan senjata, tindakan kriminal dunia maya, pembajakan kapal, dan membatasi ruang gerak teroris.

Tidak hanya itu, blueprint ini juga menekankan pada aspek penanganan bencana alam dan respon darurat. Namun yang paling penting dalam naskah ini juga mencantumkan bahwa seluruh anggota ASEAN diharuskan untuk bergerak secara efektif dan tepat waktu untuk merespon isu-isu darurat atau situasi krisis yang menghadapi ASEAN.

Action: Convene special meetings at the Leaders' or Ministerial levels in the event of crisis or emergency situations affecting ASEAN; and develop arrangements to address such situations in a timely manner (ASEAN, 2011).

Berdasarkan pemaparan di atas, telah terlihat bahwa blueprint APSC ini merupakan salah satu solusi, serta menjadi pondasi bagi penerapan lebih lanjut terhadap penanganan masalah keamanan manusia di kawasan Asia Tenggara, sehingga ASEAN secara institusi dapat berperan lebih efektif. Namun demikian yang paling penting adalah implementasi yang sungguh-sungguh dari seluruh anggota ASEAN untuk menjalankan cetak biru yang telah dihasilkan secara konsensus ini.

\section{Inisiatif Aktor Non-Negara}

Permasalahan keamanan manusia kini menjadi pembahasan para pembuat kebijakan, akademisi maupun organisasi non-pemerintah. Dari aktor non-negara ini muncul berbagai inisiatif untuk menangani berbagai permasalahan terkait dengan keamanan manusia. Mulai dari penyelesaian masalah ekonomi, pangan, kesehatan, lingkungan, maupun sosial-politik. Aspek-aspek tersebut telah menjadi aspek utama dalam penanganan keamanan manusia. Inisiatif -inisiatif yang mewakili beberapa aspek utama di atas dipaparkan sebagai berikut.

Surin Pitsuwan Project. Gagasan yang dikemukakan oleh Mantan Sekretaris Jenderal ASEAN Surin Pitsuwan (2011) mengangkat potensi ASEAN sebagai Jantung Asia. Dalam gagasannya ini, Pitsuwan menekankan bahwa ASEAN merupakan sebuah organisasi kawasan yang berupaya untuk merangkul seluruh negara anggotanya untuk mencapai kesejahteraan bersama dan distribusi yang merata. Berikut ungkapan Pitsuwan.

"Through these efforts, ASEAN is emerging as the fulcrum of geopolitical stability in Asia. What could have otherwise been a liability - ASEAN's diversity - was transformed into an asset that has set the benchmark for regional integration in a troubled and complex world. Yes, we have our share of challenges. Nevertheless, ASEAN is constantly demonstrating its determination to create a region where no member is left behind, even as we collectively pursue prosperity and an equitable distribution of our burgeoning wealth." 
Terkait dengan penanganan isu keamanan manusia, Pitsuwan (2011) menghimbau agar negara anggota ASEAN dapat bekerjasama untuk memformulasikan kebijakan dan aksi bersama terkait dengan permasalahan bencana alam, pasukan keamanan, dan keamanan laut. Bahkan ASEAN dapat bersatu untuk merespon isu perubahan iklim, perdagangan manusia, dan ketahanan pangan dan energy. Berikut pernyataan selengkapnya.

"Moreover, ASEAN is seeking to forge a clearer position on key international issues to heighten its standing on world affairs. Disaster management, peace-keeping operations, and, again, maritime-security cooperation are some of the areas in which ASEAN members can work together to formulate common policy approaches and action plans. In the years to come, ASEAN will make further progress on unified responses to climate change, human trafficking, and food and energy security."

\section{Center for Non-Traditional Security Studies Rajaratnam School of International} Studies (RSIS) Project. Program ini merupakan salah satu upaya dari kalangan akademisi dalam merespon aspek-aspek utama dalam penanganan keamanan manusia. Dalam upayanya ini RSIS (2012) menyelenggarakan programprogram sebagai berikut: 1) perubahan iklim, keamanan lingkungan, dan bencana alam, 2) energi dan keamanan manusia, 3) ketahanan pangan, 4) kesehatan dan keamanan manusia, dan 5) konflik internal dan antar-perbatasan.

Walaupun tidak secara spesifik mengkaji permasalahan keamanan manusia di kawasan Asia Tenggara, namun pusat kajian ini berlokasi di salah satu negara anggota ASEAN yakni Singapura. Tentunya kawasan Asia Tenggara tidak luput dari kajian keamanan manusia dari institusi ini.

World Wide Fund for Nature (WWF) Project on Nature Conservation. Organisasi non-pemerintah (ornop) ini sangat giat menginisiasi program-program yang terkait dengan konservasi alam. Terkait dengan salah satu aspek utama dalam keamanan manusia yakni keamanan lingkungan, Manajer Program WWF di Kalimantan, Indonesia Hermayani Putera, S.IP. mengungkapkan keberhasilan ornop ini dalam mendukung terwujudnya keamanan lingkungan yang juga di dukung oleh 3 negara anggota ASEAN yakni Indonesia, Malaysia, dan Brunei Darussalam. Heart of Borneo (HoB) demikian program ini dinamakan, dalam pelaksanaannya WWF selaku ornop bekerjasama dengan pemerintah menginisiasi Kawasan Strategis Nasional yang didalamnya terdapat Hutan Lindung, dan Taman Nasional (WWF Internationa, n.d.).

Inisiatif-inisiatif di atas menunjukkan pentingnya penanganan masalah keamanan manusia untuk diselesaikan secara tuntas dan efektif. ASEAN, Pitsuwan dan Akademisi RSIS berusaha mengetengahkan aspek-aspek utama dalam keamanan manusia, sedangkan organisasi non-pemerintah seperti WWF berupaya menyelesaikan satu aspek saja sesuai dengan misi organisasi tersebut.

\section{Kesimpulan}

Berdasarkan hasil elaborasi antara konsep, data, dan fakta di atas terhadap permasalahan keamanan manusia yang ditangani secara institusional oleh ASEAN di kawasan Asia Tenggara, terdapat beberapa hal yang bisa disimpulkan. 
1) Dalam rangka menjalankan peran secara efektif dalam menangani masalah keamanan manusia, maka negara anggota ASEAN didorong untuk meningkatkan kerjasama dan tindakan bersama dalam berbagai tingkatan: lokal, regional dan global. Di samping itu, ASEAN harus menyamakan konsep dan definisi terhadap Human Security agar dapat menjalankan fungsinya lebih baik lagi.

2) Dalam menjalankan perannya terkait masalah k eamanan manusia, ASEAN dinilai masih belum efektif, karena masih terbatas pada beberapa kasus saja yang bisa ditangani sedangkan kasus lainnya belum dapat ditangani oleh ASEAN. Ditambah lagi dengan berbagai potensi ancaman keamanan manusia yang justru berasal dari internal ASEAN.

3) ASEAN Political-Security Community (APSC) 2015 sebagai inisiasi ASEAN secara institusional dapat menjadi alternatif solusi dalam penanganan masalah keamanan manusia di Asia Tenggara, karena telah mencakup beberapa hal pokok yang telah teridentifikasi berdasarkan UNDP 1994.

4) APSC 2015 juga menjadi pondasi dan landasan bagi seluruh anggota ASEAN untuk berperan aktif dalam merespon isu-isu keamanan manusia di kawasan Asia Tenggara dalam tingkatan kementrian, hingga kepala negara.

5) Keterlibatan pembuat kebijakan, akademisi, dan organisasi non-pemerintah dalam menginisiasi penanganan masalah keamanan manusia di kawasan Asia Tenggara menunjukkan kajian ini semakin diperhatikan oleh berbagai pihak.

\section{Bibliography}

ANNAN (2000a) We The Peoples: The Role of the United Nations in the $21^{\text {st }}$ Century Chapter III [WWW] United Nations. Available from: http://www.un.org/millennium/sg/report/ch3.pdf [Accessed 30/12/12].

ANNAN (2000b) Secretary-General Salutes International Workshop on Human Security In Mongolia [WWW] United Nations. Available from: http://www.un.org/News/Press/docs/2000/20000508.sgsm7382.doc [Accessed 30/12/12].

ASEAN. (2011) Roadmap for an ASEAN Community 2009-2015. Jakarta: ASEAN Secretariat.

ASEAN (n.d.) The Founding of ASEAN [WWW] ASEAN. Available from: http://www.asean.org/asean/about-asean/history [Accessed 09/01/13].

ASEAN (n.d.) ASEAN Political-Security Community [WWW] ASEAN. Available from: http://www.asean.org/communities/asean-political-security-community [Accessed 10/01/13].

ASEAN (2011) Joint Statement of the Eighth Asean Ministerial Meeting on Transnational Crime (8th AMMTC) Bali, Indonesia, 11 October 2011 [WWW] ASEAN. Available from: http://www.asean.org/news/item/joint-statement-ofthe-eighth-asean-ministerial-meeting-ontransnational-crime-8th-ammtc-bali-indonesia-11-october-2011 [Accessed 15/0313]. 
ASEAN SECRETARIAT (n.d.) Combating Haze in ASEAN: Frequently Asked Questions [WWW] ASEAN. Available from: http://haze.asean.org/info/faq/combatinghaze [Accessed $11 / 03 / 13]$.

BAJPAI (n.d.) Definition of Human Security [WWW] SciencePo. Available from: http://www.peacecenter.sciencespo.fr/journal/issue4pdf/issue4_guestEditorial_Tadjbakhsh.pd f [Accessed: 9/01/13].

BAJPAI (2000) The Idea of a Human Security Audit. Joan B. Kroc Institute Report, 9, pp. 14.

CHEPPENSOOK (2007) The ASEAN Way on Human Security [WWW] Faculty of Political Sciences Chulalongkorn University. Available from: http://humansecurityconf.polsci.chula.ac.th/Documents/Presentations/Kasira.pdf [Accessed 10/01/13].

CIPTO. (2007) Hubungan Internasional di Asia Tenggara. Pustaka Pelajar: Yogyakarta.

CENTER FOR NON-TRADITIONAL SECURITY STUDIES RAJARATNAM SCHOOL OF INTERNATIONAL STUDIES (n.d.) RSIS Programme [WWW] Nanyang Technological University. Available from: http://www.rsis.edu.sg/nts/article.asp?sid=48 [Accessed 20/03/13].

DEPARTMENT OF STATE UNITED STATES OF AMERICA (2010) Trafficking in Persons Report 2010 [WWW] Department of State USA. Available from: http://www.state.gov/j/tip/rls/tiprpt/2010/ [Accessed 15/03/13].

FATKURROHMAN. (2010) Isu dan Realita Konflik Kawasan. Yogyakarta: Gadjah Mada University Press.

FENDRIANSYAH (2011) Ketahanan Human Security di ASEAN [WWW] Universitas Pasundan. Available from: http://digilib.unpas.ac.id/files/disk1/11/jbptunpaspp-gdlachmadfend-537-3babiii.pdf [Accessed 10/01/13].

HUMAN RIGHTS WATCH (2013) Malaysia: Backsliding on Rights [WWW] Human Rights Watch. Available from: http://www.hrw.org/news/2013/02/01/malaysiabacksliding-rights [Accessed 11/03/13].

HUMAN RIGHTS WATCH (2013) Cambodia Escalating Violence, Misuse of Courts [WWW] Human Rights Watch. Available from: http://www.hrw.org/news/2013/02/01/cambodia-escalating-violence-misusecourts [Accessed 11/03/13].

HUMAN SECURITY NETWORK (n.d.) Introduction to Human Security Network [WWW] Human Security Network. Available from: http://www.humansecuritynetwork.org/menu-e.asp [Accessed 30/12/12]. 
KONTRAS (n.d.) Daftar Kejahatan HAM Soeharto [WWW] Kontras. Available from: http://www.kontras.org/pers/teks/daftar\%20kejahatan\%20soeharto-1.pdf [Accessed 11/03/13].

NUGRAHA (2013) Myanmar Masih Lakukan Pelanggaran HAM [WWW] Okezone. Available from:

http://international.okezone.com/read/2013/02/01/411/755351/myanmar-masihlakukanpelanggaran-ham [Accessed 11/03/13].

OGATA (1999) Human Security: a Refugee Perspective [WWW] UNHCR. Available from: http://www.unhcr.ch/refworld/unhcr/hcspeech/990519.htm [Accessed 30/12/12].

OGATA (1998) Inclusion or Exclusion: Social Development Challenges For Asia and Europe [WWW] UNHCR. Available from:

http://www.unhcr.ch/refworld/unhcr/hcspeech/27ap1998.htm [Accessed: 30/12/12].

PITSUWAN (2011) The ASEAN: Heart of Asia [WWW] Project Syndicate. Available from: http://www.project-syndicate.org/commentary/the-asean-heartof-asia [Accessed 20/03/13].

PRASETYONO (2003) Human Security [WWW] Propatria Institute. Available from: http://propatria.or.id/loaddown/Paper\%20Diskusi/Human\%20Security\%20$\% 20$ Edy\%20Prasetyono.pdf [Accessed 10/01/13].

RIYANTO. (2009) ASEAN Regional Forum: Upaya Menjaga Stabilitas Kawasan Asia Pasifik. Yogyakarta: Penerbit LP3M UMY dan Jurusan HI UMY.

SIJABAT (2012) Indonesia Asks Singapore Respect Migrant Decree [WWW] The Jakarta Post. Available from: http://www.thejakartapost.com/news/2012/09/11/indonesia-askssingapore-respect-migrant-decree.html [Accessed 11/03/13].

SUARA PEMBARUAN (2012) Penyiksaan TKI di Malaysia Masih Terus Terjadi [WWW] Suara Pembaruan. Available from: http://www.suarapembaruan.com/home/penyiksaan-tki-dimalaysia-masih-terus-terjadi/17881 [Accessed: 11/03/13].

TERRIFF, et. al. (1999) Security Studies Today. United Kingdom: Polity Press.

THE JAPAN FOUNDATION JAKARTA (n.d.) Food Security: Challenges And Strategies In South And Southeast Asia [WWW] The Japan Foundation. Available from:

http://www.jpf.or.id/artikel/studi-jepang-pertukaranintelektual/food-security-challenges-andstrategies-south-and-southe [Accessed: 10/01/13].

UNDP (2006) Human Development Report Office National Human Development Report Series [WWW] United Nations. Available from: http://hdr.undp.org/en/media/NHDR_Human_Security_GN.pdf [Accessed: 10/01/13].

UNDP. (1994) Human Development Report 1994. New York: Oxford University Press. 
UNODC REGIONAL CENTRE FOR EAST ASIA AND THE PACIFIC (2008) Drug-Free ASEAN 2015: Status and Recommendations [WWW] UNODC. Available from: http://www.unodc.org/documents/eastasiaandpacific/Publications/ASEAN_2015.pdf [Accessed 15/03/13].

WHARTON SCHOOL OF THE UNIVERSITY OF PENNSYLVANIA (n.d.) Deforestation in Southeast Asia: The Future Is Being Decided in Indonesia [WWW] University of Pennsylvania. Available from: http://knowledge. wharton.upenn.edu/article.cfm?articleid=3088 [Accessed: 11/03/13].

WWF INTERNATIONAL (n.d.) Heart of Borneo Forests [WWW] WWF International. Available from: http://wwf.panda.org/what_we_do/where_we_work/borneo_forests/ [Accessed: 20/03/13]. 